UDK: 373

796.071.43:316.6

Stručni članak

Primljen 21. III. 2019.

Dragana Turić

Dječji vrtić „Trnoružica“, Vinkovci

turicdragana@gmail.com

\title{
SAMOUČINKOVITOST ODGOJITELJA I PEDAGOŠKE KOMPETENCIJE RAVNATELJA PREDŠKOLSKIH USTANOVA
}

\section{Sažetak}

Samoučinkovitost je uvjerenje pojedinca o vlastitim sposobnostima organiziranja i izvršavanja određenih akcija potrebnih za ostvarenje željenih ishoda. Ne odnosi se na objektivne sposobnosti za obavljanje konkretnoga zadatka, nego na subjektivne procjene o tome može li ga se uspješno izvršiti. Samoučinkovitost je ključni faktor ljudskoga djelovanja, on determinira i prediktor je razine postignuća koje će osoba na kraju dostići. Na njega veliki utjecaj ima kvalitetno vođenje u radnoj okolini, a preduvjet su kvalitetna vođenja ravnatelja optimalno razvijene pedagoške kompetencije. Cilj je na temelju teorijskih postavki i empirijskoga istraživanja ispitati kako odgojiteljice procjenjuju svoju samoučinkovitost, a kako pedagoške kompetencije ravnatelja predškolskih ustanova te jesu li procjene samoučinkovitosti odgojitelja povezane s procjenama pedagoških kompetencija ravnatelja. Rezultati istraživanja provedena nad uzorkom od 75 odgojiteljica dječjih vrtića Vukovarsko-srijemske županije pokazali su da odgojiteljice svoju samoučinkovitost procjenjuju visokom, kao i pedagoške kompetencije ravnatelja, te je pronađena statistički važna pozitivna povezanost procjena samoučinkovitosti odgojiteljica i njihovih procjena pedagoških kompetencija ravnatelja. U radu se objašnjavaju razlozi važnosti samoučinkovitosti u radu odgojiteljica te 
ključne uloge pedagoških kompetencija ravnatelja i njegova kvalitetnog vođenja odgojno-obrazovne ustanove.

Ključne riječi: samoučinkovitost; pedagoške kompetencije; vođenje

\section{Uvod}

Složenost ljudskoga ponašanja ne može se jednostavno objasniti samo u terminima okolinskih utjecaja i bioloških predispozicija. Kroz povijest mogu se pronaći brojni primjeri koji pokazuju kako su ekstremno uspješni pojedinci jednom tijekom svoga odrastanja bili tek prosječni, pa i imali nedostatke i iskušenja. Na primjer, Louis Pasteur, svjetski priznat francuski kemičar koji je razvio cjepiva za bjesnoću i neke druge bolesti, bio je prosječan učenik i jedan od osrednjih u kemiji. Isto tako, Albert Einstein, prema mnogima jedan od najvećih teorijskih fizičara uopće, progovorio je tek s četiri godine. Nije čitao do sedme godine, a učitelji su ga opisivali kao mentalno usporenoga, asocijalnoga i zatočenoga u svojim snovima. Gotovo svaki čovjek može iznijeti i vlastito iskustvo nerazvijenosti u nekoj domeni u određenome razdoblju svoga života. Bitna je u tim anegdotama činjenica da su ljudi sposobni suočiti se s izazovima, prevladati neuspjehe, usmjeriti svoje ponašanje i u konačnici uspjeti u svome cilju. Jedno je od objašnjenja tih uspjeha u konceptu samoučinkovitosti (usp. Henson, 2001).

Samoučinkovitost svoje temelje nalazi u socijalno-kognitivnoj teoriji, a pojam je razvio psiholog Albert Bandura. Bandura (1977) određuje samoučinkovitost kao vjerovanje u sposobnost organiziranja i izvršenja akcija potrebnih da bi se ostvario određeni tip aktivnosti, odnosno definirana je kao osobno vjerovanje koliko ćemo uspješno izvesti neki zadatak ili ponašanje. To je radije procjena vlastite kompetentnosti orijentirana prema budućim ponašanjima nego procjena aktualne razine sposobnosti. Ovo je važno jer ljudi redovito precjenjuju ili podcjenjuju svoje stvarne sposobnosti, a te procjene imaju posljedice na tijek aktivnosti i količinu truda koji ulažu u svoje planove i ponašanja (usp. Hoy - Spero, 200o; prema Ghanizadeh - Moafian, 2011). Iako je originalna ideja da je samoučinkovitost visoko usmjerena na specifično određene 
aktivnosti, utvrđeno je da očekivanja o samoučinkovitosti teže za generalizacijom, što znači da vjerovanje u uspješno izvođenje neke aktivnosti u određenome području utječe na to da imamo ista očekivanja $u$ nekome drugom području (usp. Bandura, 1977). Uglavnom se ističu tri domene samoučinkovitosti:

- socijalna samoučinkovitost - odnosi se na percipiranu sposobnost za odnose s drugim ljudima i asertivnost

- akademska/profesionalna samoučinkovitost - odnosi se na percipiranu mogućnost snalaženja u učenju/poslu te na ispunjavanje školskih/poslovnih očekivanja

- emocionalna samoučinkovitost - odnosi se na percipiranu sposobnost suočavanja s negativnim emocijama (usp. Bandura, 1977).

Percepcija samoučinkovitosti utječe na odabir vještina rješavanja problema, a ljudi s visokom percepcijom koriste djelotvornije načine za rješavanje problema jer vjeruju u svoje sposobnosti, odnosno $u$ to da se mogu nositi s teškim situacijama, bilo da se radi o akademskim/ profesionalnim, socijalnim ili emocionalnim problemima. Također, više se uključuju u situacije i aktivnosti koje dodatno jačaju i razvijaju njihove vještine te nisu skloni odustajanju zbog straha od gubitka. U svoje planove i ponašanja ulažu više truda, pažljivije odabiru aktivnosti i zadržavaju realistične i fleksibilne atribucije (usp. Ross - Gray, 2006). Primjerice, istraživanja (Bouffard-Bouchard - Parent - Larivee, 1991; prema Ghanizadeh - Moafian, 2011) su pokazala da djeca koja posjeduju višu razinu samoučinkovitosti postižu bolje rezultate u rješavanju matematičkih problema nego ona koja imaju nižu razinu, unatoč tomu što su njihove matematičke vještine na podjednakoj razini.

Uvjerenja o samoučinkovitosti utječu na ponašanje preko četiri medijacijska procesa: izbor ciljeva i ustrajnost, kognitivni procesi, emocije i odabir okoline i aktivnosti (usp. Bandura, 1997). Uvjerenja o samoučinkovitosti utječu na izbor ciljeva i ciljevima usmjerene aktivnosti, zatim na to koliko će se napora uložiti u dostizanje tih ciljeva, kao i koliko će se ustrajati kada se naiđe na poteškoće. Oblikuju tip anticipirana scenarija koji osoba konstruira i koji će eventualno isprobati. Nadalje, snažno 
utječu na vrstu i intenzitet emocionalnih reakcija na životne događaje te na odabir situacija i aktivnosti (usp. Bandura, 1997).

Procjena samoučinkovitosti važan je prediktor profesionalnoga ponašanja i uspjeha u svim područjima rada, pa tako i u okviru odgojno-obrazovnoga sustava. Učiteljska procjena samoučinkovitosti jest prosudba vlastitih sposobnosti u poticanju učenika na učenje, čak i one koji su teški i nemotivirani (usp. Henson, 2001). Bandura (1977) vjeruje da je poželjno da učitelji i odgojitelji blago precjenjuju svoje stvarne sposobnosti rada s djecom jer će to rezultirati većom motivacijom i otpornošću, što će pridonijeti maksimalnomu iskorištavanju vlastitih kapaciteta, a posljedično i većemu uspjehu u radu s djecom. Sorić (2014; prema Vican - Sorić - Radeka, 2016) navodi kako bi bilo optimalno kada bi samoučinkovitost malo nadilazila razinu postignuća u određenome trenutku jer bi to potaknulo osobu da ude u određene nove situacije bez velikoga straha. Samoučinkovitost koja je znatno iznad trenutačnih mogućnosti može biti previše optimistična i rezultirati neuspjehom.

Proteklih godina događaju se velike promjene u različitim aspektima života, a društvo ima sve veća očekivanja od odgojno-obrazovnoga sustava. To stavlja pritisak na djelatnike - učitelje, stručne suradnike i odgojitelje. Od njih se očekuje multidisciplinarnost koja podrazumijeva znanja iz specifičnoga predmeta, iz pedagogije i psihologije, vještine za vođenje djece i pružanje podrške djeci te razumijevanje društvenoga i kulturološkoga značenja odgoja i obrazovanja (usp. Jurčić, 2012; prema Nemet - Velki, 2016). Tako pojačani pritisci mogu poljuljati samopouzdanje učitelja i odgojitelja te njihov osjećaj vlastite kompetentnosti, odnosno percpeciju samoučinkovitosti.

Pri tome ravnatelj odgojno-obrazovne ustanove ima ključnu ulogu. On služi kao vodič učiteljima/odgojiteljima u njihovu razvoju i napredovanju, usmjerava ih i motivira. Kvaliteta ravnateljeva (ruko)vođenja utječe na samopouzdanje djelatnika u njihovu radu.

Decentralizacijom odgojno-obrazovnoga sustava i sve većom autonomijom školskih i predškolskih ustanova ističe se potreba vođenja i usmjeravanja ustanova i zaposlenika u njoj prema ostvarenju njezine misije i ciljeva. Ravnatelj je funkcija na koju administrativnom 
procedurom trebaju biti izabrani iskusni i afirmirani prosvjetni djelatnici, s posebnim naglaskom na potrebne kompetencije. Općenito, kompetencija se može odrediti kao (unutarnja) višedimenzionalna sposobnost pojedinca da stečeno znanje upotrijebi na različite načine $u$ konkretnim situacijama povezanima s njegovim radnim okruženjem (usp. Ćatić, 2012). Istraživanjem fenomena rukovođenja došlo se do spoznaje kako postoji pet ključnih kompetencija za optimalno ostvarenje te funkcije. To su osobna, razvojna, stručna, socijalna i akcijska (usp. Staničić, 200o). Osobna kompetencija uključuje iskrenost i dosljednost u radu, komunikativnost i pristupačnost, povjerenje u nastavnike i suradnike, dopuštanje različitih pedagoških rješenja i marljivost u radu. Razvojna kompetencija sastoji se od uvođenja inovacija, poznavanja informatičke tehnologije, racionalna organiziranja rada škole, informiranja o stručnim pitanjima i jasnoće vizije razvoja škole. Nadalje, stručna kompetencija podrazumijeva poznavanje programa i didaktičkih načela rada, poznavanje planiranja i programiranja, razumijevanja organizacije odgoja i obrazovanja i prosvjetnoga zakonodavstva te znanje vrednovanja postignuća nastavnika. Socijalna kompetencija uključuje poznavanje zakonitosti međuljudskih odnosa, umijeće motiviranja zaposlenih, sudjelovanje u rješavanju sukoba, umijeće demokratskoga rukovođenja te prepoznavanje kvaliteta vrijednih nastavnika i suradnika. Konačno, akcijska kompetencija znači praktično djelovanje, a uključuje otvorenost u radu s nastavnicima i suradnicima, slušanje i savjetodavno pomaganje $\mathrm{u}$ radu, stvaranje uvjeta i otklanjanje prepreka, isticanje rezultata vrijednih pojedinaca i sudjelovanje u rješavanju problema u školi (usp. Staničić, 2003).

Kvaliteta odgojno-obrazovne ustanove postaje ovisna o upravi, osobito o ravnatelju i njegovoj osposobljenosti za organizaciju rada škole, njegovu stručno-pedagoškom vođenju, značajkama njegove osobnosti te drugim potencijalima. Iako se dosadašnje teorijske postavke odnose uglavnom na osnovne i srednje škole, predškolska ustanova također je dio odgojno-obrazovnoga sustava te se pretpostavlja da su opće pedagoške kompetencije ravnatelja neophodne i za vođenje dječjega vrtića. 
Ravnatelji su nositelji promjena, vođe, osiguravatelji sredstava i materijalnih poboljšanja te inovatori (usp. Strehmel, 2016).

Kvaliteta rada odgojitelja kao odgojno-obrazovnoga djelatnika pod direktnim je utjecajem načina vođenja ustanove. Odgojitelji imaju više samopouzdanja u radu ako imaju povjerenja u svoje ravnatelje i njihove sposobnosti. Prema tome, ciljevi su ovoga istraživanja ispitati stupanj procjene samoučinkovitosti odgojitelja dječjih vrtića, stupanj njihove procjene pedagoških kompetencija ravnatelja te istražiti povezanost procjene samoučinkovitosti odgojitelja i njihove procjene pedagoških kompetencija ravnatelja.

U skladu s time postavljeni su sljedeći ciljevi:

1) Ispitati stupanj procjene samoučinkovitosti odgojitelja dječjih vrtića.

2) Ispitati stupanj procjene pedagoških kompetencija ravnatelja od strane odgojitelja.

3) Ispitati povezanost procjena samoučinkovitosti odgojitelja i njihovih procjena ravnateljskih pedagoških kompetencija.

Nadalje, iz ciljeva se nameću sljedeće hipoteze:

H1. Odgojitelji procjenjuju svoju samoučinkovitost visokom.

$\mathrm{H} 2$. Odgojitelji procjenjuju pedagoške kompetencije svojih ravnatelja visokima.

$\mathrm{H}_{3}$. Procjene samoučinkovitosti odgojitelja i njihove procjene pedagoških kompetencija ravnatelja pozitivno su povezane.

\section{Metodologija}

\subsection{Sudionici}

Empirijsko istraživanje provedeno je na stratificiranome uzorku od 75 odgojiteljica dječjih vrtića s područja Vukovarsko-srijemske županije. Sve su sudionice ženskoga spola, od 21 do 64 godine, s prosječnom dobi od 39,56 godina. Od ukupnoga broja sudionica njih 43 završilo je višu školu (57,3\%), a 32 završile su visoku školu, specijalizaciju i/ili doktorat 
$(42,7 \%)$. Što se tiče vrste dječjega vrtića u kojem rade, u privatnome radi 30 sudionica (40 \%), a u javnome 45 (60 \%). U gradskome vrtiću radi 60 sudionica (80 \%), a u općinskome njih 15 (20 \%). Prosječna je duljina radnoga iskustva sudionica kao odgojiteljica 12,7 godina.

\subsection{Instrumenti}

U istraživanju su korišteni sljedeći instrumenti:

Opći upitnik kojim su se prikupili osnovni sociodemografski podatci sudionika - dob, spol, stupanj obrazovanja, materijalno stanje, podatak rade li u privatnome ili javnome vrtiću, gradu ili selu te godine radnoga staža kao odgojitelja.

Skala opće samoučinkovitosti mjeri opći i stabilan osjećaj osobne učinkovitosti u suočavanju s različitim stresnim situacijama. Razvio ju je Schwarzer, a prilagodili su je Ivanov i Penezić. Originalna verzija skale sadržavala je 20, a zatim je reducirana na 10 čestica. Pouzdanost skale tipa unutarnje konzistencije iznosi između .75 i .90. Također, pokazala je i dobru konvergentnu i diskriminativnu valjanost. Uz zadovoljavajuću faktorsku strukturu na uzorcima hrvatskih ispitanika pokazala je pouzdanost tipa unutarnje konzistencije Cronbach alpha od .853 do .874 (usp. Ivanov i dr., 1998; Penezić i dr., 1999). Tvrdnje u upitniku odnose se na ispitanikovo doživljavanje sebe, a ukupan rezultat određuje se sumiranjem procjena na skali Likertova tipa od pet stupnjeva pomoću koje je sudionik procjenjivao koliko se tvrdnja odnosi na njega, od „1 = uopće se ne odnosi na mene" do ${ }_{5}=$ u potpunosti se odnosi na mene“. Veći rezultat ukazuje na veću samoučinkovitost.

Upitnik pedagoških kompetencija ravnatelja razvio je Staničić kako bi ispitao (samo)percepciju pedagoških kompetencija ravnatelja koje su potrebne za uspješno vođenje odgojno-obrazovne ustanove. Upitnik se sastoji od 25 tvrdnji prilagođenih potrebama ovoga istraživanja. $\mathrm{Na}$ tvrdnje se odgovara na skali Likertova tipa od pet stupnjeva pomoću koje je sudionik procjenjivao koliko se slaže s navedenom tvrdnjom, od ${ }_{1}=$ nimalo se ne slažem" do ${ }^{2}=$ u potpunosti se slažem“. Ukupni 
rezultat dobije se sumiranjem odgovora, a veći rezultat ukazuje na veću percepciju pedagoških kompetencija.

\subsection{Postupak}

Istraživanje je provedeno tijekom siječnja i veljače 2019. godine. Najprije je dogovorena suradnja s ravnateljima dječjih vrtića Vukovarsko-srijemske županije. Pojašnjena im je svrha istraživanja, dane su im upute za ispunjavanje upitnika te su zamoljeni da upitnike proslijede odgajateljima svojih vrtića. Nakon ispunjavanja odgajatelji su vratili upitnike svojim ravnateljima koji su ih predali istraživaču. Istraživanje je bilo dobrovoljno i anonimno. Naglašeno je da se podatci koriste isključivo u znanstvene svrhe. Sve zamoljene škole pristale su na suradnju te su pravodobno ispunile upitnike.

\subsection{Rezultati}

Rezultati ovoga istraživanja pokazuju kako odgojiteljice dječjih vrtića procjenjuju svoju samoučinkovitost, pedagoške kompetencije svojih ravnatelja te je li procjena samoučinkovitosti odgojiteljica povezana $\mathrm{s}$ njihovim procjenama pedagoških kompetencija ravnatelja. U Tablici 1 prikazani su deskriptivni podatci o prosječnim vrijednostima.

Tablica 1. Deskriptivni podatci varijabli samoučinkovitosti i pedagoške kompetencije ravnatelja.

\begin{tabular}{|l|l|l|l|l|l|}
\hline & N & Min. & Max. & M & SD \\
\hline Samoučinkovitost & 75 & 15 & 50 & 40,39 & 5,47 \\
\hline Pedagoške kompetencije ravnatelja & 75 & 37 & 125 & 107,48 & 23,19 \\
\hline
\end{tabular}

Legenda: $N=$ broj sudionika; Min. $=$ minimalni postignuti rezultat; Max. $=$ maksimalni postignuti rezultat; $M=$ aritmetička sredina; $S D=$ standardna devijacija .

Na Skali opće samoučinkovitosti maksimalni mogući broj bodova jest 5o, što je ujedno i maksimalni postignuti broj bodova. Minimalni mogući broj bodova jest 10, a minimalni je postignuti broj bodova 15. Prosječni su rezultati koje su sudionice postigle: $\mathrm{M}=40,39, \mathrm{SD}=5,47 . \mathrm{Na}$ 
temelju ovih rezultata može se zaključiti da odgojiteljice imaju srednje visoku procjenu samoučinkovitosti.

Što se tiče Upitnika pedagoških kompetencija ravnatelja, moguće je postići maksimalno 125, a minimalno 25 bodova. Postignuti maksimalni broj bodova jest 125, a minimalni 37. Prosječni su rezultati: $M=107,48$, $\mathrm{SD}=23,19$, što pokazuje da odgojiteljice pedagoške kompetencije svojih ravnatelja procjenjuju srednje visokim.

Kako bi se odabrao odgovarajući statistički postupak obrade rezultata za odgovor na treće pitanje postavljeno $u$ istraživanju, testirana je normalnost distribucija varijabli Kolmogorov-Smirnovljevim testom. Rezultati testiranja ukazali su na to da distribucija rezultata za varijablu samoučinkovitosti ne odstupa bitno od normalne, ali ne i za varijablu pedagoških kompetencija ravnatelja. Budući da uvjet normalnosti distribucija za obje varijable nije zadovoljen, koristit će se neparametrijski postupak za procjenu povezanosti samoučinkovitosti i pedagoških kompetencija ravnatelja, što se može vidjeti u Tablici 2.

Tablica 2. Spearmanov koeficijent korelacije između procjene samoučinkovitosti $i$ procjene ravnateljskih pedagoških kompetencija $(N=75)$.

\begin{tabular}{|l|l|}
\hline & Pedagoške kompetencije ravnatelja \\
\hline Samoučinkovitost & $.290^{*}$ \\
\hline
\end{tabular}

"p $p<.05$

U Tablici 2 vidljiv je rezultat procjene povezanosti između odgojiteljskih procjena samoučinkovitosti i njihovih procjena pedagoških kompetencija ravnatelja. Rezultat je pozitivan i statistički važan na razini rizika od $5 \%$, što znači da je pronađena statistički važna pozitivna povezanost između navedenih varijabli. Što je veća procjena samoučinkovitosti, to je veća i procjena pedagoških kompetencija ravnatelja, i obratno.

\section{Rasprava}

Statističkom obradom rezultata potvrđene su sve tri postavljene hipoteze.

Hipoteza H1 odnosi se na stupanj procjene samoučinkovitosti odgojitelja, koji je srednje visok. Samoučinkovitost odgojno-obrazovnih 
djelatnika važna je za kvalitetan rad s djecom, a teoriju je postavio Bandura još 1977. Prema toj teoriji vjerovanja odgojno-obrazovnih djelatnika o samoučinkovitosti povezana su s količinom truda koji učitelji ulažu u rad s djecom, s ciljevima koje si postavljaju, vlastitom otpornošću na stres i sposobnošću oporavka. Vjerovanje u vlastite sposobnosti snažan je poticaj za radnu motivaciju, optimalnu količinu ulaganja vlastitih kapaciteta i korištenje odgovarajućih strategija suočavanja sa stresnim aktivnostima i izazovima. Prema Bandurinoj socijalno-kognitivnoj teoriji, učitelji/odgojitelji koji ne smatraju da će biti uspješni u radu s djecom manje će truda uložiti u pripremu i izvođenje aktivnosti, ranije će odustati pri suočavanju sa zaprekama, čak i onda ako znaju koje su strategije rješavanja zapreka najučinkovitije. Vjerovanje o samoučinkovitosti može, dakle, biti proročanstvo koje samo sebe ispunjava (usp. Tschannen-Moran - Woolfolk Hoy - Hoy, 1998). Brojna su ranija empirijska istraživanja potvrdila utjecaj samoučinkovitosti na kvalitetu rada odgojno-obrazovnih djelatnika (usp. Anderson - Greene - Loewen, 1988; Ashton - Webb, 1986; Midgley - Feldlaufer - Eccles, 1989; Ross, 1992; prema Tschannen-Moran - Woolfolk Hoy - Hoy, 1998). Samoučinkovitost kao jednu od najvažnijih karakteristika odgojitelja koje su povezane s većom kvalitetom dječjega vrtića te većim ostvarenjima ciljeva u radu s djecom predškolske dobi potvrdila su i novija istraživanja (usp. Early i dr., 2007; Justice i dr., 2008; Locasale-Crouch i dr., 2007; prema Guo i dr., 2011).

Manje su poznati izvori vjerovanja o samoučinkovitosti odgojitelja, ali socijalno-kognitivna teorija predlaže četiri moguća predstojeća faktora: vlastito iskustvo, neizravno iskustvo, verbalna persuazija i fiziološko uzbuđenje (usp. Bandura, 1997).

Neizravno iskustvo odnosi se na situacije u kojima aktivnost izvodi neka druga osoba, a utjecaj izvedbe na promatračeva vjerovanja o samoučinkovitosti ovisi o stupnju u kojem se on identificira s modelom odnosno osobom koja izvodi aktivnost. Ako je model s kojim se subjekt blisko identificira uspješan u izvedbi zadatka, utjecaj toga iskustva na promatrača veći je nego u slučaju da nije blisko identificiran s modelom. Izvori identifikacije s modelom mogu proizaći iz stupnja zajedničkoga 
radnog iskustva, obrazovanja, spola, socijalno-ekonomskoga porijekla i sl. (usp. Bandura, 1997). Verbalna persuazija odnosi se na verbalne interakcije koje osoba prima za svoj rad, na primjer od kolega, roditelja, ravnatelja, same djece, pa čak i šire zajednice. Ako su instrukcije i povratne informacije pozitivne, doživljaj samoučinkovitosti bit će veći. Fiziološko uzbuđenje utječe na to da osjećaji zadovoljstva i užitka u radu s djecom mogu povećati doživljaj samoučinkovitosti, dok visoke razine stresa i anksioznosti povezane sa strahom od gubitka kontrole mogu rezultirati smanjenjem vjerovanja u vlastite sposobnosti (usp. Bandura, 1997).

Najistaknutijim i najvažnijim faktorom koji doprinosi samoučinkovitosti smatra se vlastito iskustvo koje proizlazi iz direktnoga rada s djecom i (ne)uspješno ostvarenih aktivnosti i zadaća. Odgojitelji koji su imali više uspješnih iskustava, pogotovo onih u kojima su se oslanjali na vlastite kapacitete, kasnije u radu mogu iskazati i veću samoučinkovitost $u$ odnosu na one koji su imali više neuspjelih situacija. Iskustvo velikim dijelom oblikuje vjerovanje u vlastite sposobnosti. Nakon što se ljudi uvjere da imaju sposobnosti koje su im potrebne za uspjeh, oni su ustrajniji i kada naiđu na poteškoće (usp. Cheung, 20o8). Stoga rezultat ovoga istraživanja, koji iskazuje relativno visoku procjenu samoučinkovitosti, nije iznenađujući jer je prosječna duljina radnoga iskustva sudionica u funkciji odgojiteljica 12,7 godina. Visokoj procjeni samoučinkovitosti zasigurno je doprinijelo i formalno obrazovanje za rad s djecom predškolske dobi. Sve su sudionice završile određeni stupanj osposobljavanja za rad odgojiteljice, s tim da su njih 43 završile višu školu (57,3\%), a čak 32 završile su visoku školu, specijalizaciju i/ili doktorat $(42,7 \%)$.

Hipoteze $\mathrm{H}_{2}$ i $\mathrm{H}_{3}$ također su potvrđene. Odgojiteljice su procijenile pedagoške kompetencije svojih ravnatelja relativno visokima te su procjene samoučinkovitosti odgojiteljica statistički bitno pozitivno povezane s njihovim procjenama pedagoških kompetencija ravnatelja.

Ravnateljeve sposobnosti i način vođenja odgojno-obrazovne ustanove povezani su s doživljajem samoučinkovitosti kod djelatnika. Djelatnici imaju veći doživljaj samoučinkovitosti u ustanovama u kojima ravnatelj inspirira zajedništvo, ohrabruje ih i motivira. Nadalje, ravnatelj 
koji koristi svoju poziciju i ovlasti kako bi svojim djelatnicima omogućio resurse potrebne za rad, koji ih štiti od ugrožavajućih faktora te omogućuje kreativnost i fleksibilnost u radu s djecom, doprinosi očuvanju i razvoju samoučinkovitosti djelatnika. Većoj samoučinkovitosti doprinosi i ravnatelj koji je prikladan model ponašanja te koristi sustav kažnjavanja i nagrađivanja po zaslugama i kvaliteti rada (usp. Hipp - Bredeson, I995; Lee i dr., I99I; prema Tschannen-Moran - Woolfolk Hoy, 2007). Odgojno-obrazovni djelatnici koji imaju pravo suodlučivanja u djelatnosti rada ustanove procjenjuju i svoju samoučinkovitost višom (usp. Moore Esselman, I992; prema Tschannen-Moran - Woolfolk Hoy, 2007).

Veza ravnateljevih kompetencija i samoučinkovitosti odgojitelja važna je jer je ona zapravo mehanizam preko kojega se s vrha upravljanja odgojno-obrazovnom ustanovom utječe na ispunjavanje njezine svrhe, a to je osiguravanje optimalnih uvjeta za uspješan odgoj i cjelovit razvoj djeteta te unaprjeđivanje djetetovih osobina i umijeća koja se počinju formirati u najranijoj dobi, a nužna su svakomu pojedincu i kasnije kako bi uspješno zadovoljavao svoje potrebe i uživao svoja prava te se odgovorno ponašao prema pravima i potrebama drugih osoba u zajednici (usp. Muraja i dr., 2012). U skladu sa socijalno-kognitivnom teorijom istraživanje (usp. Goddard, 2002; prema Kurt - Duyar, 2012) je potvrdilo da samoučinkovitost odgojitelja može biti povećana opažanjem uspješnih i podržavajućih ravnatelja.

Da bi uspješno ostvario funkciju vođenja odgojno-obrazovne ustanove $u$ administrativnome i pedagoškome području rada, ravnatelj mora imati razvijene pedagoške kompetencije. Dosadašnje instruktivno vođenje (nadzor ravnatelja kritički fokusiran na rad odgojno-obrazovnih djelatnika i njihov utjecaj na razvoj djece) polako se zamjenjuje transformacijskim, suradničkim, timskim. Ravnatelj stvara partnerske odnose sa svojim djelatnicima, ali i roditeljima, stvara motivirajuće ozračje koje regenerira novu, pozitivnu energiju. Upravo su razvijene pedagoške kompetencije predispozicija ravnatelja za prelazak na transformacijsko vođenje (usp. Staničić, 2007). Transformacijsko vođenje potiče jačanje samoučinkovitosti djelatnika jer takve vođe preoblikuju osobne ciljeve i vrijednosti u kolektivni interes. $U$ tome smislu transformacijski pristup 
vođenju naglašava emocije i vrijednosti, njeguje razvoj osobnih kapaciteta i interesa djelatnika (usp. Leithwood - Jantzi, 2005). Bass (1999; prema Kurt - Duyar, 2012) je definirao transformacijsko vodstvo kao stavljanje zajedničkih ciljeva ispred osobnih kroz karizmu, inspiraciju, intelektualnu stimulaciju i individualizirani pristup. Takve vođe govore smirenim tonom glasa, uspostavljaju kontakt očima, usklađuju geste i artikulaciju s temom govora te imaju samouvjeren i dinamičan nastup. Potiču identificiranje djelatnika s organizacijom jer se tako ostvaruju zajednička suradnja i podrška, što jača samopouzdanje i samoučinkovitost djelatnika, ali i olakšava ostvarenje ciljeva organizacije. Kroz individualizirani pristup transformacijski vođa prepoznaje kvalitete svakoga djelatnika te ga može usmjeriti na smanjenje nepotrebnih, a jačanje potrebnih kompetencija. Pruža podršku djelatnicima u svladavanju problema s kojima se suočavaju u odgojno-obrazovnome procesu (Kurt - Duyar, 2012).

Pedagoške kompetencije, uz znanje i vještine, sadrže i osobine ličnosti neophodne za kritičko promišljanje o sebi, o odgojnoj i obrazovnoj praksi te o učinkovitome vođenju odgojno-obrazovne ustanove. One omogućavaju promjenu i unaprjeđenje ravnateljevih ponašanja i oblikovanje poticajne klime škole. Jedino pedagoški kompetentan ravnatelj može biti uspješan organizator, vođa, usmjerivač, medijator, socijalni integrator i refleksivni praktičar koji može odgovarati izazovima koji su postavljeni u suvremenoj školi, cjeloživotno se usavršavati i nadograđivati svoju kompetentnost. Pedagoški kompetentni ravnatelji preduvjet su pozitivne klime odgojno-obrazovne ustanove jer omogućuju demokratsko vođenje, uvažavanje djelatnika, prilagodljivost i kreativnost u radu te potiču razvijanje učiteljskih i odgojiteljskih kompetencija. Uspješnu klimu karakteriziraju humani odnosi i povjerenje u kolektivu. Ona se smatra jednim od čimbenika koji utječu na razvoj pedagoških osobina i samopouzdanja nastavnika i odgojitelja, na kvalitetu njihova odgojnog i obrazovnog rada te međuljudske odnose i radne uvjete (usp. Brust Nemet - Velki, 2016). Jača vjerovanja o samoučinkovitosti iskazali su odgojitelji koji su percipirali klimu predškolske ustanove pozitivnom. Također su procijenili i snažan osjećaj zajedništva. Nepovoljna klima 
ustanove umanjuje doživljaj samoučinkovitosti odgojitelja, a karakteriziraju je pretjerani zahtjevi, slab moral, nedostatak priznanja za rad, neodgovarajuće plaće, loši međuljudski odnosi, profesionalna izolacija, nesigurnost i otuđenje (usp. Tschannen-Moran - Woolfolk Hoy, 2007).

Ravnatelji odgojno-obrazovnih ustanova suočavaju se s brojnim izazovima i zahtjevima suvremenoga pristupa, ali njihova je ključna uloga u poticanju razvoja odgojiteljskih kompetencija i posljedično samoučinkovitosti, osiguranju uvjeta u kojima se mogu razvijati vještine potrebne za rad s djecom, omogućavanju odgojiteljima da sudjeluju u procesu donošenja odluka, osiguranju odgovarajućih povratnih informacija koje će služiti odgojiteljima kao uvid u vlastite jake i slabe sposobnosti i kompetencije. Ravnatelj je dužan prepoznati i one odgojitelje koji su nedostatnih kompetencija i negativnih stavova te pravovremeno i točno reagirati u smjeru ispravljanja neadekvatnosti. Na taj način ravnatelji jačaju samoučinkovitost odgojitelja, što doprinosi kvalitetnu ispunjenju svrhe predškolske ustanove. Ove zahtjeve voditeljske funkcije može uspješno ispuniti jedino pedagoški kompetentan ravnatelj (usp. Brinson - Steiner, 2007).

Budući da je u ovome istraživanju ispitana povezanost procjena samoučinkovitosti odgojiteljica i njihovih procjena pedagoških kompetencija ravnatelja, ne može se sa sigurnošću zaključiti o uzročno-posljedičnoj vezi. Može se pretpostaviti da su odgojiteljice procijenile pedagoške kompetencije svojih ravnatelja u skladu sa svojom procjenom samoučinkovitosti jer su osobe općenito sklone projicirati sliku o sebi i svojim sposobnostima na okolinu. Naime, prema Festingerovoj teoriji kognitivne disonance (1957; prema Aronson - Wilson - Akert, 2005) svaka osoba teži konzistentnosti svoga mišljenja, stavova i ponašanja. Tako odgojiteljice koje procjenjuju svoju samoučinkovitost visokom imaju tendenciju procijeniti visokima i pedagoške kompetencije svojih ravnatelja kako bi, na nesvjesnoj razini, održale slaganje mišljenja o svojim i ravnateljskim kapacitetima. 


\section{Nedostatci istraživanja i preporuke za buduća istraživanja}

Ovo je istraživanje ograničeno jer je provedeno u samo jednoj županiji, pa se ne može sa sigurnošću generalizirati na predškolski sustav Republike Hrvatske. Nadalje, korišten je konstrukt pedagoških kompetencija u cjelini, a ne po specifičnim domenama. Što se tiče budućih istraživanja, preporučuje se da temu prošire na predškolske ustanove diljem Hrvatske, da istraže utjecaj specifičnih domena modela pedagoških kompetencija na samoučinkovitost odgojitelja te da istraže specifične domene samoučinkovitosti u kontekstu predškolskoga sustava.

\section{Zaključak}

Istraživanje je provedeno na uzorku od 75 odgojiteljica dječjih vrtića Vukovarsko-srijemske županije, prosječne dobi od 39,56 godina i prosječne duljine radnoga iskustva kao odgojiteljica od 12,7 godina. Ciljevi istraživanja bili su ispitati stupanj procjene samoučinkovitosti odgojitelja dječjih vrtića, stupanj njihove procjene pedagoških kompetencija ravnatelja te istražiti povezanost procjene samoučinkovitosti odgojitelja i njihove procjene pedagoških kompetencija ravnatelja. Rezultati istraživanja pokazali su da odgojiteljice procjenjuju svoju samoučinkovitost visokom, pedagoške kompetencije ravnatelja također procjenjuju visokima te ukazuju na statistički važnu pozitivnu povezanost procjena samoučinkovitosti odgojiteljica i njihovih procjena pedagoških kompetencija ravnatelja. Samoučinkovitost odgojitelja ključni je faktor ispunjenja svrhe predškolske ustanove jer utječe na motivaciju i stupanj ulaganja truda u izvršenje neke aktivnosti. Kvalitetno vođenje ustanove doprinosi jačanju samoučinkovitosti odgojitelja, a ključne su predispozicije takva vođenja optimalno razvijene pedagoške kompetencije ravnatelja koje su preduvjet transformacijskoga vodstva i stvaraju pozitivnu klimu odgojno-obrazovne ustanove, što pak doprinosi razvoju samoučinkovitosti odgojitelja. 


\section{Literatura}

- Aronson, Elliot - Wilson, D. Timothy - Akert, Robin M. (2005) Socijalna psihologija, MATE d.o.o., Zagreb.

- Bandura, Albert (1977) „Self-efficacy: Toward a unifying theory of behavioral change", Psychological Review, god. LXXXII, br. 2, str. $191-215$.

- Bandura, Albert (1997) Self-efficacy: the exercise of control, W.H. Freeman and company, New York.

- Brinson, Dana - Steiner, Lucy (2007) Building collective efficacy: How Leaders Inspire Teachers to Achieve. Issue Brief, TheCenter for Comprehensive School Reform and Improvement, Washington.

- Brust Nemet, Maja - Velki, Tena (2016) „Socijalne, emocionalne i pedagoške kompetencije nastavnika kao prediktori različitih aspekata kulture škole“, Croatian Journal of Education, god. XVIII, br. 4, str. 1087 - 1119.

- Cheung, Hoi Yan (2008) „Teacher efficacy: a comparative study of Hong Kong and Shanghai primary in-service teachers", The Australian Educational Researcher, god. XXXV, str. 103 - 123.

- ČAtí́, Iva (2012) „Kompetencije i kompetencijski pristup obrazovanju", Pedagogijska istraživanja, god. IX, br. 1-2, str. $175-189$.

- Ghanizadeh, Afsaneh - Moafian, Fatemeh (2011) „The relationship between Iranian EFL teachers' sense of self-efficacy and their pedagogical success in Language Institutes", Asian EFL Journal, god. XIII, br. 2, str. $249-272$.

- Guo, YING i dr. (2011) „Exploring factors related to preschool teachers' self-efficacy“, Teaching and Teacher Education, god XXVII, br. 5 , str. $961-968$.

- Henson, Robin K. (2001) Teacher Self-efficacy: Substantive Implications and Measurement Dilemmas, University of North Texas, Texas. 
- Kurt, Turker - Duyar, Ibrahim - Calik, Temel (2012) „Are we legitimate yet? A closer look at the casual relationship mechanisms among principal leadership, teacher self-efficacy and collective self-efficacy", Journal od Management Development, god. XXXI, br. 1, str. $71-86$.

- Leithwood, Kenneth - JAntzi, Doris (2005) „Transformational leadership“, Essentials of School Leadership, Paul Chapman \&Corwin, Thousand Oaks, str. $31-43$.

- Muraja, Jasmina i dr. (2012) Priručnik za samovrednovanje ustanova ranog i predškolskog odgoja i obrazovanja, Nacionalni centar za vanjsko vrednovanje obrazovanja, Zagreb.

- Ross, John - Gray, Peter (2006) „Transformational leadership and teacher commitment to organizational values: the mediating effects of collective teacher efficacy", School Effectiveness and School Improvement, god. XVII, br. 2, str. 179 - 199.

- Staničić, Stjepan (200o) Vodenje odgojno-obrazovne djelatnosti $u$ školi, doktorska disertacija, Filozofski fakultet u Rijeci, Rijeka.

- Staničić, StJePAn (200o) „Povezanost kompetencija ravnatelja i pedagoga za vođenje u školi“, Odgoj, obrazovanje i pedagogija u razvitku Hrvatskog društva, Hrvatski pedagoško-književni zbor, Zagreb.

- Staničić, Stjepan (2007) „Menadžment u obrazovanju - pravci razvoja“, Previšić, Vlatko - Šoljam, Nikša Nikola - HrVatić, Neven, Pedagogija prema cjeloživotnom obrazovanju i društvu znanja, sv. 2, Hrvatsko pedagogijsko društvo, Zagreb.

- Strehmel, Petra (2016) „Leadership in Early Childhood Education: Theoretical and Empirical Approaches", Journal of Early Childhood Education Research, god. V, br. 2, str. 344 - 355.

- Tschannen-Moran, Megan - Woolfolk Hoy, Anita - Hoy, WAYNE (1998) „Teacher efficacy: Its meaning and measure“, Review of Educational Research, god. LXVIII, br. 2, str. $202-248$. 
- Tschannen-Moran, Megan - Woolfolk Hoy, Anita (2007) "The differential antecedents of self-efficacy beliefs of novice and experienced teachers", Teaching and Teacher Education, god. XXIII, br. 6, str. $944-956$.

- Vican, Dijana - Sorić, Izabela - Radeka, Igor (2016) Upravljanje odgojno-obrazovnom ustanovom: Kompetencijski profil ravnatelja, Sveučilište u Zadru, Zadar. 


\section{PRESCHOOL TEACHERS' SELF-EFFICACY AND PRINCIPALS' PEDAGOGICAL COMPETENCIES}

\section{Abstract}

Self-efficacy is the belief in one's ability to organize and perform specific actions which are necessary to accomplish desired goals. It does not refer to objective abilities to carry out a specific action, but to subjective estimate if the action can be performed successfully. Self-efficacy is the key factor of human functioning, it is a determinant and a predictor of the degree of success that will eventually be achieved. Self-efficacy is largely affected by qualitative leadership in work environment. The precondition of qualitative principal's leadership are his optimally developed pedagogical competencies. On the basis of theoretical hypotheses and empirical research this paper seeks to examine the way preschool teachers evaluate their self-efficacy and their principals' pedagogical competencies. The relationship between preschool teachers' evaluation of self-efficacy and their evaluation of principals' pedagogical competencies is also studied in the paper. The study included 75 preschool teachers in Vukovar-Srijem County. The results have shown that the teachers highly evaluate their self-efficacy as well as the principals' pedagogical competencies. The statistically significant positive relationship between preschool teachers' evaluation of self-efficacy and their evaluation of principals' pedagogical competencies is found. The paper elaborates reasons of importance of self-efficacy in preschool teachers' work as well as the key roles of principals' pedagogical competencies and their quality management of the educational institution.

Keywords: self-efficacy; pedagogical competencies; management 